\title{
APPLICATION OF AGRICULTURAL LOAN IN MUSLIM COMMUNITY: A STUDY BASED ON KEKIRAWA DIVISIONAL SECRETARIAT OF ANURADHAPURA IN SRI LANKA
}

\author{
Mohamed Haniffa Mohamed Nairoos ${ }^{1}$, RM. Risly ${ }^{2}$, \\ Uthuman Kandu Mohammed Muhees ${ }^{3}$ \\ ${ }^{I}$ Senior Lecturer, Department of Islamic Studies, FIA,South Eastern University of Sri Lanka \\ ${ }^{2}$ BA (Hons) in Islamic Banking and Finance,South Eastern University of Sri Lanka \\ ${ }^{3}$ BA (Hons) in Islamic Thought \& Civilization, South Eastern University of Sri Lanka, MA (UPDN)
}

Correspondent Name: MHM Nairoos

Article DOI: https://doi.org/10.36713/epra8442 DOI No: 10.36713/epra8442

\begin{abstract}
Agriculture plays most important role in Sri Lankan economy like some other developing nations in South Asia such as India, Bangladesh, Pakistan, Nepal and Bhutan. In this way, the agricultural farming sector is identified as a key tool for the economic development in Sri Lanka and it helps to effectively utilize the invaluable resources of the country such as green lands and appropriate climate as it should be and to significantly boost the wealth of the country as well. Furthermore, as it helps to expand the level of GDP, the Interest rates as well as the inflation rates are mostly estimated at present depending on the level of agricultural cultivation sector in the country. It is noteworthy to point out at this occasion that as Sri Lanka is mainly an agricultural nation the most people are involving in individual and joint venture farming activities. At the same time, it is also very important to mention here that most people who involve in agricultural cultivation reach the banks and financial institution for the purpose of getting loans to meet their agricultural financial needs. In this context, this research aims to identify the loan systems which are implemented in agricultural sector among the Muslim community, especially among Muslim farmers who are living in Kekirawa divisional secretariat in Anuradhapura district. The research would be extremely significance due to there is no sufficient previous studies find concerning with agricultural loan systems among Muslim community in particular research area in Sri Lanka. This research is designed as mixed method with the inclusion of qualitative and quantitative data which collected in term of finding the correct solutions and providing appropriate recommendations. The findings of the research reveals that the farmers who live in Kekirawa divisional secretariat of Anuradhapura do not depend and connect with banks or other financial institutions to get any advances, but they use to fulfil their needs of capital for farming from money lenders, shopkeepers, friends relatives and NGOs. Therefore, the system should be introduced under the Islamic banks and financial institutions to promote the Shariah compliance products and interest free loan systems not only for Muslim farmers but also to all citizens who wish to involve in agricultural cultivations. Moreover, NGOs and shopkeepers who provide agricultural credit services should be adapted in accordance with the Islamic Shariah compliance.
\end{abstract}

KEY WORDS: Agriculture, Loan Systems, Farmers, Kekirawa. Shariah Compliance, Islamic Banks

\section{INTRODUCTION}

Nowadays, agriculture is the major source of household income and it plays the key role of the Gross Domestic Product (GDP) of many countries in the world especially in agricultural nations. Many scholars sturdily consider that agriculture sector is an important factor for development of individuals, families, communities and nations. Moreover, the remarkable agricultural growth has positive advantages to the rural and the urban poor people through its effectiveness in reducing the prices of agricultural food products as well as significantly contributes the prosperous of nations. Simultaneously, the consequence of agricultural growth 
enormously reflects on the industrial growth as well due to providing a lot of raw materials to the various industrial sectors. Thus, the agricultural advancement is necessary for improving the supply of raw materials for the agro based industries, especially in developing countries. The shortage of agricultural goods has its impact on industrial production and a consequent increase in the general price level. It will impede the growth of the country's economy. The flour mills, rice sellers, oil \& dhal mills, bread, meat, milk products sugar factories, wineries, jute mills, textile mills and numerous other industries are based on agricultural products (Praburaj L. 2018).

Since Sri Lanka is mainly an agricultural nation, many crops such as tea, rice, coffee, coconut products, rubber, cinnamon, various fruits as well as vegetables are remarkably produced and some products are exported. Especially tea, rubber, coffee and cinnamon productions play the most important role of the gross export revenue of the country. Development and exports are usually observed as a device for economic growth. More exports generate more income, raise more foreign exchange and indirectly promote economic growth through competition. The agriculture sector is the basis of economy in Sri Lanka. This sector contributes $10.1 \%$ of Gross Domestic Product and $28.5 \%$ of the employment (CBSL, 2014). Agricultural export contributes $25.1 \%$ share of the total exports in Sri Lanka (CBSL, 2014). In this way, the contribution of agricultural export to the economic growth is vital importance (Vanitha Prasannath, 2015). Even if the country is mainly as an agricultural nation, the facilities provided for farmers to utilize in agricultural doings particularly for seeds, fertilizer, pesticides, plough, harvest, wages for labors as well as the better irrigation should be seriously considered. Moreover, it is very important to consider that farmers how get their finance and other facilities as a result of faceable heavy challenges and difficulties during their farming period.

In this background most farmers reach the banks, financial institutions and personal creditors for the purpose of getting loans and invest them in their farming production sectors. Nowadays lot of banks and financial institutions in Sri Lanka provide agricultural loans similar to rest of the countries in the world. It is remarkable at this juncture to identify some popular agricultural loan system in Sri Lanka for farmers such as Commercial Agri Loans for Professionals provided by Commercial Bank PLC, Surusara loan scheme of Seylan bank PLC and Agriculture loan scheme of Bank of Ceylon. However, the loan systems provided by conventional banks, financial institutions and personal creditors are based on interest based. Therefore, in many occasions particularly during the period of agricultural loss, these farmers face many challenges and stresses. These farmers are mostly effected on account of the heavy burden of interest based agricultural loans they got. If they face unexpected losses due to climate change or other factors they are seriously struggling to pay these interest based loans and sometimes they sell their paddy lands or living houses as well to repay loans. At the same time, it is also notable that nowadays there are flexible interest free loan systems offered by Islamic banks and financial institution which called Qarl Hasan.

However in Kekirawa DS division which is the research area, it could not be found any agricultural loans which are provided by Islamic banks and financial institutions for their farming customers. In this situation, lots of Muslim farmers are using some different ways in getting loans to carry on their agricultural activities. Consequently the topic, Application of agricultural loans in Muslim community: A study based on Kekirawa Divisional secretariat in Sri Lanka is taken for this study. The research area is situated in Anuradhapura District and there are more than 10 Muslim villages here which consisted more farmers. These farmers face heavy financial crisis to utilize in their farming efforts. As a result, some of these farmers get loans from conventional banks and financial institutions with interest; in the meantime, several of them use some other different ways to get loans due to unavailability of loan systems from Islamic banks and financial institutions. As a consequence, the researcher would like to find by means of this research that how the farmers among the Muslim community in Kekirawa divisional secretariat get do loans from different ways. And, how they repay their loans obtained, as well as the loan systems used are under Shariah compliance or are not.

\section{PROBLEM STATEMENT}

The most people, who enthusiastically involve in agricultural endeavours in Muslim community in Kekirawa Divisional Secretariat Area, do not have enough capital to manage their expenses rising on it. As a result, these farmers are interesting to take the agricultural loans for the purpose of pesticides, plough, harvest, and wages for the labourers. They obtain these agricultural loans from several ways. Consequently, it is very important to find that those ways practiced in obtaining loans are mainly based on Shariah compliant or do not and are these farmers face any challenges and complicatedness due to the loan systems they got.

Farmers buy their necessary goods and items to utilize in cultivation from particular shops and stores situated in the city area. Subsequent to made cultivation either they got profit or loss from harvesting their repayment loan scheme must be settled with extra amount of money or without.

However, the agricultural loans which obtained by most farmers in Muslim community in Kekirawa divisional secretariat for their agricultural needs and in developing their measures of farming have to be analyzed that the contracts made by them are comply with Shariah basis and recognized to practice. Islam has 
presented wonderful loan system which the needy people can be assisted by wealthy people for the sake of Almighty Allah and without any purpose of extra gaining all the way through prohibited ways. Therefore, the research problem of the study is that what are the agricultural loan systems practiced among the Muslim farmers in the research area and to examine that those are implemented under Shariah compliant or not.

\section{RESEARCH QUESTIONS}

Specifically, this research has been carried out to explore the answers to the following questions with the aim of solving the research problem of the study

RQ1: What are the agricultural loan systems in practice among the Muslim community in Kekirawa divisional secretariat?

RQ2: How does the Muslim community get agricultural loans away from the banks and financial institutions and how do they repay them?

RQ3: Are the agricultural loan systems experienced in the Muslim community based on Shariah compliant or not?

\section{OBJECTIVES OF THE RESEARCH \\ Primary Objective}

The primary objective of the research is as follow

RO1: To investigate the agricultural loan systems in practice among the Muslim community in Kekirawa divisional secretariat

\section{Secondary Objectives}

The secondary objectives of the research are

RO2: To identify the agricultural loans obtained by Muslim farmers except the banks and regulated financial institutions and how do they repay them

RO3: To find out that the agricultural loan systems experienced in the Muslim community based on Shariah compliant or not

\section{LITERATURE REVIEW}

The farmers tended towards the replacement of traditional methods of farming with scientific and developed methods. For instance, use of High Yield Variety (HYV) of seeds, fertilizers, pesticides, irrigation, machinery and equipment etc. requires huge amount of capital which is beyond the capacity of most of the farmers. Due to this the farmers compulsorily depend upon borrowed funds. This causes the increasing demand for credit. So, in respect of transformation of traditional or subsistence farming into commercial farming, the importance of agricultural credit has increased comparatively (Mr. Joy Joseph P, December, 1994).

The informal sector has the legitimacy and blessing of rural communities. Assuming no other lucrative alternative is available, it is more in line with the rural tradition for farmers to go to the middleman or to resort to the better-off neighbours or the money lenders in order to dispose of surplus grains (i.e., beyond needs of the household) or sell livestock in order to circumvent the need for a short-term credit. Households in the rural sector also have at their disposal endogenous and informal saving and credit associations that are capable of servicing their physical/financial requirements (Dr. Mahmoud A. Gulaid)

Informal lenders can be moneylenders, traders and agro-processing firms. They adopt different monitoring mechanisms which would be expensive, or even impossible for banks. Besides, informal lenders can interlink the terms of the transactions in the credit market with those of transactions in the product markets. For instance, a trader-lender may offer lower prices on fertilizers and pesticides to farmers who borrow from him because the use of these inputs reduces the probability of default (Qi Zhou, Xiangfeng Chen and Shuting Li, 2018).

Agricultural credit has played a vital role in supporting agricultural production in the state. Green Revolution characterized by a greater use of inputs like fertilizers, seeds and other inputs (Jeeban Jyoti Mohanty, October 2017)

Agricultural credit has helped enhance the agricultural productivity of the farmers. With such a credit facility, farmers will have a better access to improved seeds, fertilizer, pesticides and better irrigation facility. Thus, farmer friendly agricultural credit services should be extended and deepened even in the rural areas. It will help the farmers of the rural area attain a higher level of technical efficiency and higher farm productivity. (Nepal Rastra Bank, 2014) 


\section{RESEARCH DESIGN AND METHODOLOGY}

\section{Sampling area}

Muslim farmers who get the agricultural loans in Kekirawa divisional secretariat are the target population group of this study.

\section{Data Collection Method}

The relevant data to carry out the study successfully collected mainly from two sources as follows, and the research is designed as mixed mode including quantitative and qualitative data.

\section{Primary Data}

The primary data will be collected through questionnaire and interview methods for this mixed mode study.

\section{Questionnaire}

A total of 150 sets of Questionnaires were prepared and distributed to Muslim farmers respondents who are the customers of agricultural loan in particular research area. However, 112 responses were received among them. For the purpose of this study, the sampling technique used is probability sampling based on simple random sampling. A simple random sample is a subset of individuals and sample chosen from a larger set of population. Selection of sample is among the people specially farmers who get the agricultural loan for their agricultural activities.

\section{Interview}

Researchers get information about agricultural loans by interview of 20 selected farmers from the Muslim community. There are some questions structured related to getting agricultural loan systems and repaying it has been used to collect information from them as the necessity for this study.

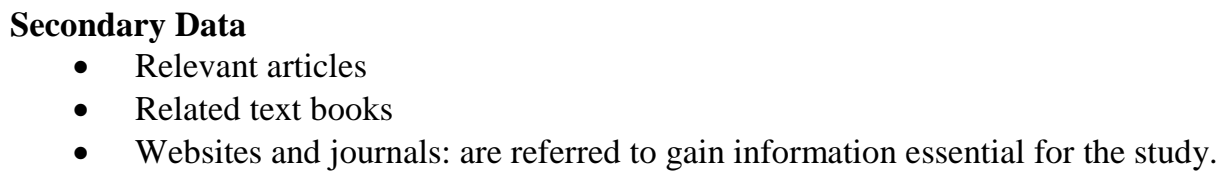

- Relevant articles

- Related text books

- Websites and journals: are referred to gain information essential for the study.

\section{Method of Measurement}

For data analysis, descriptive analytical techniques such as column charts, pie charts, graphical illustration and etc were used. For the statistical analysis, the researcher applied MS-Excel software package which person correlation, regression and analysis tests will be calculated to analyze the primary data obtained from the questionnaire.

\section{RESULTS AND DISCUSSION}

Table 1.1 Financing System for Agriculture

\begin{tabular}{|c|c|c|}
\hline Financing System & Frequency & Percentage \\
\hline Own Capital & 2 & $2 \%$ \\
\hline Agricultural loan & 21 & $19 \%$ \\
\hline Both & 89 & $79 \%$ \\
\hline Total & $\mathbf{1 1 2}$ & $\mathbf{1 0 0 \%}$ \\
\hline
\end{tabular}

According to above table, out of 112 respondents, the financing system of large number of Muslim farmers for agriculture is in both arrangements such as own capital and agricultural loan. In view of that, $79 \%$ out of $100 \%$ is both system, meanwhile agricultural loan is $19 \%$ and only own capital is $02 \%$.

Table 1.2 Credit Obtaining System

\begin{tabular}{|c|c|c|}
\hline Credit Obtaining System & Frequency & Percentage \\
\hline In cash & 82 & $75 \%$ \\
\hline In goods & 20 & $18 \%$ \\
\hline Both cash and goods & 8 & $7 \%$ \\
\hline Total & $\mathbf{1 1 0}$ & $\mathbf{1 0 0 \%}$ \\
\hline
\end{tabular}


EPRA International Journal of Multidisciplinary Research (IJMR) - Peer Reviewed Journal

Volume: 7| Issue: 9| September 2021|| Journal DOI: 10.36713/epra2013 || SJIF Impact Factor 2021: 8.047 || ISI Value: 1.188

Based on above table, large number of respondents gets the agricultural loan by cash that $75 \% .18 \%$ of them get the agricultural loan by goods, and $07 \%$ of them use the both system cash and goods.

Table 1.3 Ways of Credit Accessed

\begin{tabular}{|c|c|c|}
\hline Ways of Credit Accessed & Frequency & Percentage \\
\hline Friend/Relative & 24 & $22 \%$ \\
\hline Money Lender & 28 & $25 \%$ \\
\hline Local Trader/Shop Keeper & 24 & $22 \%$ \\
\hline Farmers Organization & 2 & $2 \%$ \\
\hline Informal savings group & 4 & $4 \%$ \\
\hline Buyer/Trader(Contract farming) & 1 & $1 \%$ \\
\hline NGO & 21 & $19 \%$ \\
\hline Other & 6 & $5 \%$ \\
\hline Total & $\mathbf{1 1 0}$ & $\mathbf{1 0 0 \%}$ \\
\hline
\end{tabular}

Table 1.4 Loan Repaying Medium

\begin{tabular}{|c|c|c|}
\hline Loan Paying Medium & Frequency & Percentage \\
\hline By Cash & 65 & $59 \%$ \\
\hline By Goods & 45 & $41 \%$ \\
\hline Total & 110 & $100 \%$ \\
\hline
\end{tabular}

Table 1.5 Repaying System by Cash

\begin{tabular}{|c|c|c|}
\hline Repaying System by Cash & Frequency & Percentage \\
\hline Basic Loan Amount & 19 & $29 \%$ \\
\hline Extra Amount with Basic Loan & 46 & $71 \%$ \\
\hline elay Charge with Basic Amount & 0 & $0 \%$ \\
\hline Total & 65 & $100 \%$ \\
\hline
\end{tabular}

Table 1.6 Repaying System by Goods and Products

\begin{tabular}{|c|c|c|}
\hline Repaying system by goods & Frequency & Percentage \\
\hline Agricultural product as a repayment of loan amount & 20 & $44 \%$ \\
\hline $\begin{array}{c}\text { Agricultural product and other some additional things as a } \\
\text { repayment of loan amount }\end{array}$ & 25 & $56 \%$ \\
\hline Total & $\mathbf{4 5}$ & $\mathbf{1 0 0 \%}$ \\
\hline
\end{tabular}

In accordance with the above tables No $1.3,1.4,1.5 \& 1.6$

\begin{tabular}{|c|c|c|}
\hline Money lender, by cash, basic loan amount & 0 & $0 \%$ \\
\hline Moneylender, by cash, Extra amount with loan amount & 27 & $96 \%$ \\
\hline $\begin{array}{l}\text { Moneylender, by good, Provide an agricultural product as a repayment of loan } \\
\text { amount. }\end{array}$ & 0 & $0 \%$ \\
\hline $\begin{array}{l}\text { Moneylender, by good, Provide an agricultural product and other some } \\
\text { additional things as a repayment of loan. }\end{array}$ & 1 & $4 \%$ \\
\hline Local trader, by cash ,basic loan amount & 6 & $25 \%$ \\
\hline Local trader, by cash, Extra amount with loan amount & 12 & $50 \%$ \\
\hline $\begin{array}{l}\text { Local trader, by good, Provide an agricultural product as a repayment of loan } \\
\text { amount. }\end{array}$ & 5 & $21 \%$ \\
\hline $\begin{array}{l}\text { Local trader, by good, Provide an agricultural product and other some } \\
\text { additional things as a repayment of loan. }\end{array}$ & 1 & $4 \%$ \\
\hline Friend/ Relative, by cash, basic loan amount & 12 & $50 \%$ \\
\hline Friend/ Relative, by cash, Extra amount with loan amount & 0 & $0 \%$ \\
\hline
\end{tabular}




\begin{tabular}{|l|r|r|}
\hline $\begin{array}{l}\text { Friend/ Relative, by good, Provide an agricultural product as a repayment of } \\
\text { loan amount. }\end{array}$ & 10 & $42 \%$ \\
\hline $\begin{array}{l}\text { Friend/ Relative, by good, Provide an agricultural product and other some } \\
\text { additional things as a repayment of loan. }\end{array}$ & 2 & $8 \%$ \\
\hline & 0 & $0 \%$ \\
\hline NGO, by cash, basic loan amount & 0 & $0 \%$ \\
\hline NGO, by cash, Extra amount with loan amount & 0 & $0 \%$ \\
\hline $\begin{array}{l}\text { NGO, by good, Provide an agricultural product as a repayment of loan } \\
\text { amount. }\end{array}$ & 21 & $100 \%$ \\
\hline $\begin{array}{l}\text { NGO, by good, Provide an agricultural product and other some additional } \\
\text { things as a repayment of loan. }\end{array}$ & & \\
\hline & 64 & $66 \%$ \\
\hline BASED ON INTEREST & 33 & $34 \%$ \\
\hline FREE INTEREST & \multicolumn{2}{|c|}{} \\
\hline
\end{tabular}

Muslims are second most population in Kekirawa division in Anuradhapura district and most of them depend on agriculture in this population, As well as most of them face capital problem when they start cultivating. Because of this problem they find more ways to solve this problem.

By the way $25 \%$ farmers borrow money from money lender. As a borrower when they repay they use money to repay or else they pay by agricultural products.

To repay in this two methods they use four ways.

1- Repay the basic amount.

2- Extra amount with basic amount.

3- Provide an agricultural product as a repayment of loan amount.

4- Provide an agricultural product and other some additional things as a repayment of loan.

In this background, second way is used by $96 \%$ of Muslim farmers as well as the fourth way is used by $04 \%$ of farmers to repay the amount that they borrow.

Moreover, $22 \%$ of farmers use local trader / shopkeeper to repay their money. These farmers also used cash and goods to repay the loan. By using these two methods they use 04 ways to repay the loan. From this $25 \%$ repay basic loan amount, $21 \%$ repay by providing the agricultural product as the repayment of loan amount, $4 \%$ provide the agricultural product and other some additional things as a repayment of loan amount.

Furthermore $22 \%$ of farmers get loans from friends and relatives. They also use same methods to borrow money and repay the money. $50 \%$ of them repay the basic amount. $42 \%$ repay by providing agricultural product as repayment of loan amount. $8 \%$ of them provide the agricultural product and other some additional thinks as a repayment of loan amount.

$19 \%$ percent of farmers borrow money / loan from NGO. To repay the loan they use money as well as agricultural products as methods and $100 \%$ of them repay by providing the agricultural products and other some additional as a repayment of loan amount.

As well as other $12 \%$ of farmers use farmers' organization, buyer / trader (contract farming) to get their loans. When they repay more than basic amount, $34 \%$ percent of them ignore the payment that they have to pay.

The present of responds those who deal with interest is $66 \%$ and the interest free dealing estimated as $34 \%$. This finding express the most of the population related with interest.

There is another separate system similar to loan method that called as "oththi". It means if there is a person with a land, and another person with money. But both of them are not satisfied as a consequence of the person who has land need money to cultivate and the person who has money need a land. So they agreed and come for a contract that providing money to the person who has land without or lacking of money for agricultural activities for the purpose of cultivation. Thus, the owner of land would be paid amount of money by the investor or the money owner until the particular land is used in cultivation activities.

Another way is also in the research area that there are persons with name " $\mathrm{A}$ " and " $\mathrm{B}$ ", and here the person " $\mathrm{A}$ " has money and the person " $\mathrm{B}$ " has land. " $\mathrm{A}$ " invests in the land of " $\mathrm{B}$ " and " $\mathrm{A}$ " is demanded for a big amount of share by the person "B". "B" must want to repay the amount.

\section{CONCLUSION AND RECOMMENDATION}

It is notable that some of loan systems which are currently being offered in Sri Lanka are interest free. There are some instances identifiable for this that laptop loan to university students and motorcycle loan to government servants. In any case, a formal loan scheme for agriculture is no longer in full form in government. 
The fact is that agriculture subsidies are not fully paid. Therefore, the Agricultural Departments in Sri Lanka should consider the basic livelihood of farmers and in the manner systematically introducing the agricultural loan scheme on a yearly basis to consider the economy of the country. Land and subsidies for a farmer must be properly calculated and credited in each year. By appointing a qualified officer the farming divisions in each category should repay the loan for the loss of agricultural profit and loss. This loan system should not be directly linked to the bank, but the departments have to intervene and give agricultural credit and the Department of Recycling should be forwarded.

The money lender, NGOs, local trader and shopkeeper have to deal with non-interest payments and calculate the returns in terms of profit and losses. These companies should implement the Islamic banking system in their respective companies and institutions. At the same time, the Islamic banks and Islamic Windows in Sri Lanka should implement the agrarian credit system in their banks and institutions in the country. Currently the Islamic banks and financial institutions functioning in Sri Lanka are providing their Islamic banking services in line with the wealthy and wealthy individuals in the accounting institution community.

Allah says in the Quran the wealth should not be concentrated only to the rich. He tells us that economic activities should not be cantered on the rich.

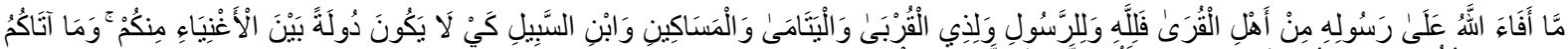

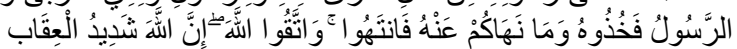

"And what Allah restored to His Messenger from the people of the towns - it is for Allah and for the Messenger and for [his] near relatives and orphans and the [stranded] traveler - so that it will not be a perpetual distribution among the rich from among you. And whatever the Messenger has given you - take; and what he has forbidden you - refrain from. And fear Allah; indeed, Allah is severe in penalty" (Surah al-hashr: 07)

So there is a huge responsibility for each Islamic bank and financial institutions. The basic purpose of each of the banks and institutions is that everyone who is in the community should take on daily Islamic banking without having to pay their daily payments. They also have the responsibility to protect all those who are in the community from interest based on the needs and objectives of the farmers and the accounting agencies should also provide agricultural credit for each Islamic banking institution in the country.

Thus, every Islamic banking and accounting firms should introduce a system of agricultural loans to the benefit of farmers and introduce agricultural loans such as introduction of households such as home loan, land loan and leasing services in the Islamic way of Mudharaba, Murabaha, Musharaka and Salam. Agricultural credit is a direct profit but not indefinitely, however indirectly for the country's economy and Islamic banks. For example we can clearly understand it through GDP.

While the above recommendations are being implemented, there is an expectation that the farmers would be able to obtain agricultural loans in the community without any interest and able to utilize these funds in smoothly developing their farming measures.

\section{REFERENCES}

1. Dr. Mahmoud Gulaid, A. (1995). Financing Agriculture through Islamic Modes and Instruments: Practical Scenarios and Applicability. Jeddah: Islamic Research and Training Institute Islamic Development Bank.

2. JeebanJyotiMohanty. (2017). Agriculture Credit Market in Odisha: A Source of Sustainable Livelihood for the Farmer. International Journal of Scientific and Research Publications, 7(10) 291-301.

3. Joy Joseph, P. (1994). A study Of Agricultural and Rural Development Banks in Kerala with Special Reference to Funds Management (PhD Thesis). Cochin University of Science and Technology, Cochin - 22

4. Nepal rastra bank. (2014). Agricultural credit and its impact on farm productivity: A case study of kilali district.

5. Praburaj I. (2018). Role of Agriculture in the Economic Development of a Country. International Journal of Commerce. Vol.6 (03), 01-05. Doi:10.5281/zenodo.1323056.

https://www.researchgate.net/Publications/334645070_Role_of_Agriculture_in_the_Economic_Development_of_ a_Country

6. Qi Zhou, Xiangfeng Chen and Shuting Li. (2018). Innovative Financial Approach for Agricultural Sustainability: A Case Study of Alibaba. China: School of Management, Fudan University.

7. Vanitha Prasannath. (2015). Impact of Agricultural Export on Economic Growth in Sri Lanka. Proceedings of National Symposium on Agriculture. Faculty of Science, Eastern University of Sri Lanka .p. 56 - 65. http://www.researcgate.net/publication/341130610 